INTERNATIONAL JOURNAL OF RESEARCHES IN BIOSCIENCES, AGRICULTURE AND TECHNOLOGY

(C) VISHWASHANTI MULTIPURPOSE SOCIETY (Global Peace Multipurpose Society) R. No. MH-659/13(N) www.vmsindia.org

\title{
EFFECT OF SEED SIZE AND SHAPE ON GERMINATION AND SEEDLING VIGOUR IN HYBRID VARIETIES OF SUNFLOWER
}

\author{
R. Gadewar ${ }^{1}$, S. Charjan ${ }^{2}$, A. Lambat ${ }^{1}$, R. Deotale ${ }^{2}$, \\ V. Babhulkar ${ }^{2}$, R. Parate ${ }^{2}$ and P. N. Charde ${ }^{1}$ \\ ${ }^{1}$ Sevadal Mahila Mahavidyalaya \& Research Academy, Nagpur, M.S., India. \\ ${ }^{2}$ Dr. P D K V'S College of Agriculture, Nagpur, M.S., India. \\ lambatashish@gmail.com
}

\begin{abstract}
:
In the present studies investigation were conducted on sunflower hybrid varieties to study the influence of seed size (large, medium and small) on germination and seedling vigour. The germination potential and seedling vigour was significantly more in the large and medium size than the ungraded and smaller ones respectively. First count germination, plumule and radicle length, speed of germination, dry matter production and seed vigour index positively correlated with seed size. The optimum sieve for grading the seeds of these varieties have been fixed. The seed technological aspects encompassing these aspects are yet to be investigated. The findings of the present studies would benefit the farmer in obtaining superior crop.
\end{abstract}

Keywords: seedling vigour, hybrid,

\section{Introduction:}

Sunflower is a rich source of vegetable oil of high quality but it is yet to gain impetus in our country. One of the major problem encountered in sunflower production in India is the lack of good quality seeds. The desirable attributes of quality seed is uniformity in size. This leads to poor and erratic field emergence and failure of seedling establishment in the field which subsequently results into low productivity. It is therefore, desirable to determine the optimum size of seed that promote better germination, growth and vigour in the field. Evidences of seed size effects on various aspects of plant growth was also reported in sunflower by Robinson (1974), Trehan et al. (1977), Mrcos Filno et al (1986) and Dharmalingam and Basu (1989).

The present study was undertaken to determine the optimum seed size for obtaining higher germination and field stand, besides producing healthy and vigorous seedling for successful seed production.

\section{Material and Methods:}

Two varieties of sunflower (Helianthus annuus L.) viz., PKVSH-27 and KBSH-1 were used in the various phases of this study, produced in kharif, 2014. Seed size grading was done using round perforated metal sieves having hole diameter 15/64" (6.00 mm), 13/64" (5.2 $\mathrm{mm}$ ) and $11 / 64 "(4.4 \mathrm{~mm})$. The seeds retained by the above sieves were designated as G1, G2 and G3 respectively while the bulk as UG. By drawing the required number of samples from G1, G2, G3 and UG to evaluate the performance of the seed lots in various laboratory studies, following test and observations were made: (i) Weight of 100 seed from $4 \times 100$ seeds on dry weight basis,

(ii) Standard germination and first count under laboratory conditions in between towel paper media (Anon., 1985),

(iii) Length of plumule and radicle, dry matter production, as on last day ( $7^{\text {th }}$ day) of germination count for ten (10) randomly selected normal seedlings (Anon., 1985),

(iv) Speed of germination (Maguire, 1962),

(v) Seed vigour index (Abdul Baki and Anderson, 1973) and field emergence (Anon., 1985).

\section{Results and Discussion:}

It become evident, from the results (Table 1) that the hundred seed weight in each treatment showed a close association with the size of seed. Aquiar and Nakane (1983) reported that the seed weight was directly proportional to the seed size.

The laboratory germination differed with respect to seed size and there was decreasing trend in germination with the respective decrease in seed size. The PKVSH-27 and KBSH-1 variety exhibited highest germination in G1 followed by G2, UG and G3 respectively. The probable reason for low germination in smallest grade may be due to large presence of immature seeds. According to Sundararaj and Ramkrishnan (1973), the shrivelled ground nut seeds tended to produce more of abnormal seedlings. Gurbanov and Bertii (1970) reported that the increased germination percentage in bigger seed is associated with increased activity of radox-enzyme which helps in breaking down the complex food material into simple soluble sugar at a faster rate. 
Among the seed grades, the large seed grade was superior for germination compared to small grade. These findings are in agreement with those reported by Senthilkumar Kalingarayar and Dharmalingam (1980) in sunflower, Kaur and Srivastava (1982) in tritical and Kalakannavar et al. (1989) in wheat.

All seed grades affect the vigour test parameters. Large size grade (G1) of sunflower varieties viz., PKVSH-27 and KBSH-1 were found superior in first count germination, plumule and radicle length, speed of germination, and seed vigour index. Among the seed grade G1, G2, G3 and UG, the G1 and G2 were found superior in all the vigour test parameters. McDaniel (1969) reported that the increased root length, dry matter production and vigour index of seedling from bigger seeds may be due to efficient utilization of large food serves and greater amount of production of energy which arc positively correlated with seed size.

Seed vigour evaluations confirmed the superiority of the large and medium size seeds over the small and ungraded ones. Similar observations in different parameters of seed vigour test have been reported by Harper and Obeid (1967) in linseed, Sivasubramanian and
Ramkrishnan (1977) in sunflower, Ashok Kumar et al. (1979) in sunflower, Kalakannavar et al. (1989) in wheat and Dharmalingam and Basu (1989) in sunflower.

The percentage of field emergence recorded by large size seed could be ascribed to the large food reserve contained in them. The seed size and seed weight may therefore, serve as indices of field emergence potential. Under field condition G1 grade, recorded maximum emergence of $88 \%$ and $84 \%$ in PKVSH-27 and KBSH-1 followed by G2, UG and G3 respectively. In the field bolder seeds showed higher germination over smallest seeds. These differences in germination capacity might be due to the fact that small seeds failed to emerge from the soil due to their low vigour. Similar observations have been reported by Elsaeed (1967) in soybean, Kalakannavar et al. (1989) in wheat and Dharmalingam and Basu (1989) in sunflower.

Thus it becomes evident that here is correlation between seed size to germination and vigour. Therefore, in sunflower varieties viz., PKVSH-27 and KBSH-1, size grading of bulk seed lots with a sieve having 15/64" (6.00) would ensure separation of sound seed for better field performance.

Table. 1- Effect of (seed) Achene sizes on germination (\%) and Seedling vigour in Sunflower varieties.

\begin{tabular}{|l|l|l|l|l|l|l|l|l|l|}
\hline Characters & $\begin{array}{l}\text { Seed } \\
\text { weight }\end{array}$ & $\begin{array}{l}\text { Standard } \\
\text { germination } \\
(\%)\end{array}$ & $\begin{array}{l}\text { First Count } \\
\text { germination } \\
(\%)\end{array}$ & $\begin{array}{l}\text { Plumule } \\
\text { length } \\
(\mathrm{cm})\end{array}$ & $\begin{array}{l}\text { Radical } \\
\text { length } \\
(\mathrm{cm})\end{array}$ & $\begin{array}{l}\text { Seed of } \\
\text { germination }\end{array}$ & $\begin{array}{l}\text { Dry } \\
\text { weight } \\
(\mathrm{gm})\end{array}$ & $\begin{array}{l}\text { Seed } \\
\text { Vigour } \\
\text { Index } \\
(\text { SVI) }\end{array}$ & $\begin{array}{l}\text { Field } \\
\text { emergence } \\
(\%)\end{array}$ \\
\hline PKVSG-27 & & & & & & & & & \\
\hline G1 & 5.53 & 93.00 & 88.00 & 16.20 & 21.80 & 44.42 & 0.53 & 3534.00 & 88.00 \\
\hline G2 & 4.12 & 86.00 & 84.00 & 13.44 & 18.12 & 40.33 & 0.40 & 2714.16 & 80.00 \\
\hline G3 & 3.97 & 70.00 & 60.00 & 8.14 & 11.26 & 32.83 & 0.28 & 1358.00 & 58.00 \\
\hline UG & 2.98 & 84.00 & 83.00 & 11.80 & 13.65 & 40.19 & 0.34 & 2137.80 & 77.00 \\
\hline & & & & & & & & & \\
\hline KBSH-1 & & & & & & & & & \\
\hline G1 & 5.83 & 90.00 & 86.00 & 16.36 & 20.78 & 43.92 & 0.49 & 3342.60 & 84.00 \\
\hline G2 & 4.42 & 81.00 & 78.00 & 13.00 & 17.34 & 41.16 & 0.38 & 2457.54 & 73.00 \\
\hline G3 & 4.02 & 64.00 & 51.00 & 8.04 & 10.86 & 31.76 & 0.27 & 1209.60 & 56.00 \\
\hline UG & 3.18 & 76.00 & 73.00 & 10.80 & 12.59 & 40.15 & 0.32 & 1777.64 & 69.00 \\
\hline
\end{tabular}

G1 = Large Size Seed, G2 = Medium Size Seed, Ungraded Seed.

References:

Abdul-Baki, A. A. and Anderson, J. D. 1973. Vigour determination in Soybean by multiple criteria. Crop Sci., 10:31-34.

Aquiar, I. B. DE and Nakane, J. T. 1983. Seed size of Gucalyptus citriodora: influence on germination and vigour. Seed Abstr., 12(8): 2576 .
G3 = Small Size Seed,

UG

Ashokkumar, T. N; Giriraj, K; Prasad, T. G. and Vidyashankar, T. S. 1979. Influence of seed lest weight on yield and growth parameters in sunflower. Seed Res., 7(2): 141-144.

Anonymous 1985. International rules for seed testing. Seed Sci. and Technol., 13: 299-513. 
Dharmalingam, C. and Basu, R. N. 1989. Influence of achene size on germination and vigour potential in sunflower. Seed Res., 17(2): 128-134.

Elsaccd, E. A. K. 1967. Seed Size as a vandal difference in broad beans (Viciafcba L.). J.Agric. Sci., 68 : 69-73.

Gurbanov, Ya. V. and Bertii, Z.G. 1970. Initial growth intensity in winter wheat in relation to seed size. Field Crop Abstr., 25(2): 1275.

Harper, J. L. and Obcid, M. 1967. Influence of seed size and depth of scroing on the establishment and growth of varieties of fibre and oil seeds flax. Crop. Sci., 7: 527-532.

Kaur, S. and Srivaslava, A. K. 1982. Effect of seed size and chemical composition on germination and seedling growth in triticale. Indian J. PI. Physiol., 25(4): 427-431.

Kalakannavar, R. M; Shashidhara, S.D. and Kulkarni, G. N. 1989. Effect of grading on quality of wheat seeds. Seed Res., 17(2): 182185.

Maguire, J. D. 1962. Speed of germination: aid in selection and evaluation of seeding emergence and vigour. Crop Sci., 2: 176-177.
McDaniel, R. G. 1969. Relationship of seed weight, seedling vigour and mitochondrial metabolism in barley. Crop Sci., 9(6): 823-827.

Mrcos Filno, J; Komatsu, Y. H; Novembre, A. D. L. C; Fratin, P. and Demetrio, C. G. B. 1986. Seed size and performance of sunflower: 1 Germination. Seed Abstr., 12(1): 88.

Robinson, R.G. 1974. Sunflower performance relative to size and weight of achenes planted. Crop Sci., 14: 616-618.

Senthilkumar Kalingarayar, A. and Dharmalingam, C. 1980. Influence of seed sizes on seed quality of Sorghum. Madras Agric. J., 67: 435-461.

Sivasubramanian, S. and Ramkrishnan, V. 1977. Relationship between seed size and seedling vigour in sunflower. Seed Res., 5: 6-10.

Sundararaj, D. D. and Ramkrishnan, V. 1973. Seed quality determination in Arachis hypogaea L. Madras Agric. J., 60: 1453-61.

Trehan, K. B., Hirachand, S. and Mehta, S. K. 1977. Effect of different seed size on yield and some quantitative characters of sunflower. Madras Agric. J., 64 : 174-176. 